\title{
Viral Agents Associated with Poult Enteritis in Croatian Commercial Turkey Flocks
}

\author{
Ivana Lojkić ${ }^{1}$, Marina Biđin ${ }^{2}, Z_{\text {denko Biđin }}^{2}$, Milivoj Mikec ${ }^{3}$ \\ ${ }^{1}$ Department of Virology, Croatian Veterinary Institute, Zagreb, Croatia \\ ${ }^{2}$ Department of Poultry Diseases, Faculty of Veterinary Medicine, University of Zagreb, Croatia \\ ${ }^{3}$ Poultry Centre, Croatian Veterinary Institute, Zagreb, Croatia
}

Received May 12, 2009

Accepted September 8, 2009

\begin{abstract}
From 2003 to 2006, samples of intestinal content and spleens from 10-day-old to 6-week-old fattening turkeys showing clinical signs of enteritis were analyzed by specific PCR and RT-PCRs for detection of haemorrhagic enteritis virus (HEV), avian reovirus (ARV), turkey astrovirus-2 (TastV-2), and turkey coronavirus (TCV). A total of 23 flocks from 6 farms were included in the study. Specific sequence for HEV hexon gene was present in 6 samples from turkeys younger than and in one turkey at 6 weeks of age. A product of TAstV-2 capsid gene was detected in 17/23 intestinal content samples. A 626-bp band of sigma A (S2) encoding gene segment from avian reovirus was present in three samples, all from the same farm. Sequence analysis of 450 bp fragment of avian reovirus sigma A encoding gene sequence showed that our strain had the identity of $91.3 \%$ with the strains $138,2408,1733,919$, T6, and Os161. No TCV specific PCR band was found in any sample. Four flocks were positive simultaneously for HEV and TAstV-2, and three flocks on TastV-2 and ARV. Severity of poult enteritis described in our study is caused by immunosuppressive TastV-2 in combination with HEV or ARV.
\end{abstract}

Turkeys, avian reovirus, turkey astrovirus-2, haemorrhagic enteritis virus, turkey coronavirus

Poult enteritis complex (PEC) is an infectious disease of turkey poults aged up to 6 weeks. The disease is characterized by diarrhoea, decreased growth (stunting), increased morbidity and mortality and immunosuppression (Barnes et al. 2000). In cases of increased mortality the disease is referred to as Poult enteritis and mortality syndrome (PEMS) (Barnes and Guy 2003). PEC was first described in North America and is characteristic for regions where turkeys are commercially produced (Barnes and Guy 2003). The aetiology of the disease is complex. Several viral and bacterial agents have been isolated from birds exhibiting clinical signs associated with PEMS. The first viral agent associated with this syndrome was a turkey coronavirus (Lin et al. 1996) but later studies demonstrated that turkey coronavirus was not required for disease (Barnes et al. 1997). Carver et al. (2001) found flocks with PEMS that were negative for turkey coronavirus. Other viruses that play an important role in the aetiology of PEMS are astroviruses (Yu et al. 2000; Koci et al. 2000) and reoviruses (Simmons et al. 2000, Heggen-Peay et al. 2002). More recently, PEMS has been described affecting poults in Great Britain, resulting in a first report of this disease there (Culver et al. 2006).

Astroviruses are known as the causative agents of acute gastroenteritis in mammals and turkeys (Bridger 1980; McNulty et al. 1980; Reynolds et al. 1987a; Goodgame 2001), as well as acute nephritis in chickens (Imada et al. 2000). Turkey astrovirus (TAstV) was first identified in 1980 in the intestinal contents of poultry with diarrhoea (McNulty et al. 1980). Infection usually occurs during the first four weeks of age (Reynolds et al. 1987b) and is more prevalent than infections by any other enteritis-causing agent in poultry (Reynolds and Saif 1986; Reynolds et al. 1987a; Saif et al. 1985). Two decades later, a novel astrovirus TAstV-2 was isolated from a group of turkeys with PEMS which is molecularly distinct from the earlier TAstV, sharing only $35 \%$ nucleotide sequence in the capsid gene (Koci et al. 2000). TAstV-2 primarily replicates in the thymus. Most enteric

\footnotetext{
Address for correspondence:

Ivana Lojkić

Croatian Veterinary Institute, Department of Virology

Phone: 38516123627

Fax: 38516423670

E-mail: ilojkic@vef.hr

Savska cesta 143, 10000 Zagreb, Croatia

http://www.vfu.cz/acta-vet/actavet.htm
} 
viruses replicate only in the intestines and have a limited effect on non-intestinal organs.

Turkey coronavirus (TCV) is a member of Group 2 of the genus Coronavirus of the family Coronaviridae; (Lai and Cavanagh 1997). It is the cause of the bluecomb disease, an acute, highly contagious enteric disease of turkeys (Nagaraja and Pomeroy 1997). It replicates only in the intestinal epithelium and the epithelium of bursa of Fabricius (Naqi et al. 1972; Patel et al. 1975). The matrix and nucleocapsid genes of the turkey coronaviruses had $>99 \%$ identity with the corresponding genes of bovine coronavirus (BCV) (Dea et al. 1990; Verbeek and Tijssen 1991). More recently, other coronavirus isolates from turkeys have been found to be closely related to the Infectious bronchitis virus of chicken (IBV) (Guy et al. 1997; Breslin et al. 1999).

Avian reoviruses (ARV) have been isolated from turkeys with PEMS (Heggen-Peay et al. 2002) and also from chickens and ducks with enteric and respiratory problems, viral arthritis/tenosynovitis, malabsorption and stunting (Rosenberger and Olson 1997).

Haemorrhagic enteritis is a disease of turkeys of 4 weeks of age and older, and is well known in Croatian turkey production (Mazija et al. 1979). It is characterized by depression, splenomegally, intestinal haemorrhage and immunosuppresion (Pierson and Domermuth 1997). Haemorrhagic enteritis virus (HEV) is a group II avian adenovirus and it replicates in the spleens and caecal tonsils of infected turkeys but not in the intestines. The affected spleen is enlarged and marbled (Suresh and Sharma 1996).

At the end of 2002, symptoms similar to PEC appeared at the largest turkey farm in Croatia. Turkeys between 2-6 weeks of age showed diarrhoea, dehydration, weight loss and loss of appetite. Older turkeys showed milder symptoms. The purpose of the present study was to detect viruses (TCV, TastV-2, ARV and HEV) from the clinical samples of turkey flocks responsible for outbreaks of acute enteritis. It is also a first confirmation of the presence of TAstV-2 and ARV in poults with enteritis in Croatia.

\section{Materials and Methods}

\section{Samples}

From 2003 to 2006, tissue samples (intestine, spleen) from affected poults, ranging from 10 days to 6 weeks of age, were received for virological examination. The poults (Nicholas line) were from a multi-age farm, divided into six houses with about 1100 birds in each. Organ samples from a total of 23 flocks were analyzed. One sample corresponds to a pool of 5-10 organ samples per flock.

Positive control viruses spotted on FTA cards, TCV (strain), ARV (strain) and TAstV-2 (strain) were provided by Dr. Holly Sellers (University of Georgia, Athens, GA). Antigen for agar gel immunodiffusion test (Poultry Centre, Zagreb, Croatia) served as positive control for HEV detection.

Extraction of viral nucleic acids, RT and PCR

For HEV, DNA was extracted from $50 \mathrm{mg}$ of turkey spleens; for detection of TAstV-2, ARV and TCV RNA was extracted from turkey intestinal suspensions. Extraction of DNA from $\sim 50 \mathrm{mg}$ of spleens was performed using NucleoSpin Tissue (Machery-nagel, Germany) according to the manufacturer's instructions. Viral RNA from intestinal suspensions was extracted using QIAmp Viral RNA Mini Kit (Qiagen, Germany) following the manufacturer's instructions. Intestinal suspensions were prepared by cutting slices from the ileo-caecal junction, and homogenizing in sterile PBS; one part of the content was mixed with 5 parts of sterile PBS (140 mM $\mathrm{NaCl}, 2.7 \mathrm{mM} \mathrm{KCl}, 8.0 \mathrm{mM} \mathrm{Na}_{2} \mathrm{HPO}_{4}, 1.5 \mathrm{mM} \mathrm{KH}_{2} \mathrm{PO}_{4}$ ), frozen and thawed $3 \times$ and centrifuged for $10 \mathrm{~min}$ at $3000 \times g$. Extraction of RNA from FTA cards was also performed using QIAmp Viral RNA Mini Kit (Qiagen). Prior to extraction, a $3 \mathrm{~mm}$ disk was placed in $200 \mu \mathrm{l}$ of $10 \mathrm{mM}$ of Tris-HCL and $0.1 \mathrm{mM}$ of EDTA, with a pH value of 8.0, vortexed, and incubated for $30 \mathrm{~min}$ at room temperature. Reverse transcription (RT) procedures were performed using $2 \mu \mathrm{l}$ RNA in a $20 \mu \mathrm{l}$ reaction volume containing $20 \mathrm{U}$ RNaseH-M-MLV reverse transcriptase (SuperScript $^{\mathrm{TM}}$ III reverse transcriptase, Invitrogen, Carlsbad, CA, USA), 5 pmol of random hexamer primer, $0.5 \mathrm{mM}$ dNTPs, $10 \mathrm{mM}$ dithiothreitol, $50 \mathrm{mM}$ Tris- $\mathrm{HCl}, 75 \mathrm{mM} \mathrm{KCl}$ and $3 \mathrm{mM} \mathrm{MgCl}$. This was incubated at $45{ }^{\circ} \mathrm{C}$ for $50 \mathrm{~min}$ followed by $72{ }^{\circ} \mathrm{C}$ for $10 \mathrm{~min}$. Approximately $50 \mathrm{ng}$ of DNA (or $2 \mu \mathrm{l}$ of cDNA) were incubated together with $0.25 \mu \mathrm{M}$ of each specific primer and $12.5 \mu 12 \mathrm{X}$ concentrated Go Taq Green Master Mix (1.25 U Taq polymerase, 0.4 pmol dNTPs, $3 \mathrm{mM} \mathrm{MgCl}_{2}$ ) (Promega, USA) in a total volume of $25 \mu \mathrm{l}$. The PCR was carried out on GenAmp PCR System 2400 (Applied Biosystems, Foster City, CA, USA) with the conditions different for each virus. Sequences and references of primers are shown in Table 1. Ten $\mu 1$ of PCR products were analyzed by 1 or $2 \%$ agarose gel electrophoresis and stained with ethidium bromide. One ARV positive PCR product was 
Table 1. Primer names, sequences and PCR product sizes for the PCR and RT-PCR assays used in study.

\begin{tabular}{|l|l|c|c|}
\hline Virus & \multicolumn{1}{|c|}{ Primer sequence } & Product & Reference \\
\hline HEV & $\begin{array}{l}\text { HEV1F: TAC TGC TGC TAT TTG TTG TG } \\
\text { HEV2R: TCA TTA ACT CCA GCA ATT GG }\end{array}$ & Hexon: $1646 \mathrm{bp}$ & Hess et al. (1999) \\
\hline TAstV-2 & $\begin{array}{l}\text { MKCAP8F: TCA TCA TCC TCT CAC ACT GG } \\
\text { MKCAP19R: AGC AGC AGT AGG TGG CAG TG }\end{array}$ & Capsid ORF 2: 849 bp & Koci et al. (2000) \\
\hline ARV & $\begin{array}{l}\text { S3-NF: ATG GAG GTA CGT GTG CCAAA } \\
\text { S3-NR: TCC AAA AGT CAG CAT CCA CG }\end{array}$ & S3: 460 bp & This manuscript \\
\hline ARV & $\begin{array}{l}\text { S2-PAF: ACT TCT TYT CTA CGC CTT TCG } \\
\text { S2 PAR: ATY AAW DCW CGC ATC TGC TG }\end{array}$ & S2: 626 bp & Zhang et al. (2006) \\
\hline TCV & $\begin{array}{l}\text { TCV-NF: GGT AGC GGT GTT CCT GA } \\
\text { TCV-NR: CCC TCC TTA CCT TTA GT }\end{array}$ & Nucleocapsid: 598 bp & Sellers et al. (2004) \\
\hline
\end{tabular}

purified by QIAquick purification kit (Qiagen). Sequencing was carried out in both directions using the Big Dye Terminator 1.1 Cycle Sequencing kit (Applied Biosystems) as recommended by the manufacturer. Sequencing analysis was performed on an automatic sequencer ABI PRISM 310 Genetic Analyzer (Applied Biosystems). The nucleotide sequence obtained from our ARV strain was named Muntrilj06 and was deposited in GenBank with accession number FJ606766.

Multiple alignment and phylogenetic analysis

The sequence data were initially aligned to known sequences using the basic BLAST search program. Sequence analysis was performed with the Lasergene 6 package (DNAstar Inc., Madison, USA). Phylogenetic analyses of the 450-bp fragment of sigma

Table 2. Results of the PCR and RT-PCR analysis of turkey organ samples on HEV, TastV-2 and ARV. TCV was not detected in any sample.

\begin{tabular}{|l|c|c|c|c|c|}
\hline $\begin{array}{l}\text { Farm } \\
\text { /year/ }\end{array}$ & $\begin{array}{c}\text { Age } \\
\text { /weeks/ }\end{array}$ & $\begin{array}{c}\mathrm{HEV} \\
\text { /spleen/ }\end{array}$ & $\begin{array}{c}\text { TASTV-2 } \\
\text { /intestinal } \\
\text { content/ }\end{array}$ & $\begin{array}{c}\text { ARV-S2 } \\
\text { /intestinal } \\
\text { content/ }\end{array}$ & $\begin{array}{c}\text { ARV-S3 } \\
\text { /intestinal } \\
\text { content/ }\end{array}$ \\
\hline $\mathrm{A} / 03$ & 3 & + & + & - & - \\
\hline $\mathrm{B} / 03$ & 3 & - & + & - & - \\
\hline $\mathrm{C} / 03$ & 3 & - & + & - & - \\
\hline $\mathrm{C} / 03$ & 3 & + & + & - & - \\
\hline $\mathrm{B} / 03$ & 5 & + & - & - & - \\
\hline $\mathrm{C} / 03$ & 4 & - & - & - & - \\
\hline $\mathrm{D} / 04$ & 4 & + & + & - & - \\
\hline $\mathrm{E} / 04$ & 6 & + & - & - & - \\
\hline $\mathrm{E} / 04$ & 5 & + & + & - & - \\
\hline $\mathrm{C} / 04$ & 1 & - & + & - & - \\
\hline $\mathrm{C} / 04$ & 3 & - & + & - & - \\
\hline $\mathrm{C} / 04$ & 4 & + & - & - & - \\
\hline $\mathrm{E} / 05$ & 3 & - & - & - & - \\
\hline $\mathrm{E} / 05$ & 2 & - & + & - & - \\
\hline $\mathrm{E} / 05$ & 2 & - & + & - & - \\
\hline $\mathrm{E} / 05$ & 2 & - & - & - & - \\
\hline $\mathrm{F} / 05$ & 2 & - & + & - & - \\
\hline $\mathrm{C} / 05$ & 2 & - & + & + & - \\
\hline $\mathrm{D} / 05$ & 3 & - & + & - & - \\
\hline $\mathrm{C} / 06$ & 2 & - & + & + & - \\
\hline $\mathrm{C} / 06$ & 4 & - & + & + & - \\
\hline $\mathrm{D} / 06$ & 2 & - & + & - & - \\
\hline $\mathrm{E} / 06$ & 1 & - & + & - & - \\
\hline $\mathrm{B} 010+$ & 2 & + & & & \\
\hline
\end{tabular}
A encoding gene were conducted using MEGA version 3.1 (Kumar et al. 2004) using the maximum parsimony method with 500 bootstrap replicates.

\section{Results}

Case history

Enteritis was usually observed in turkeys of 2-5 weeks of age, and it was clinically manifested with diarrhoea, loss of appetite, dehydration and anorexia. The disease lasted for 14 days. Sick birds were eating litter rather than pelleted food which resulted in constipation of gizzard and death. Mortality did not exceed $1 \%$ per week. At the end of 2005, together with described symptoms, poults had much more stunted growth and uneven gait, they were usually down on the hocks and reluctant to move.

\section{PCR and RT-PCR}

Agarose gel electrophoresis of PCR products of DNAs from organ samples originated from 23 flocks (Table 2) showed that Bold +: sample Muntrilj06 HEV sequence was present in six 


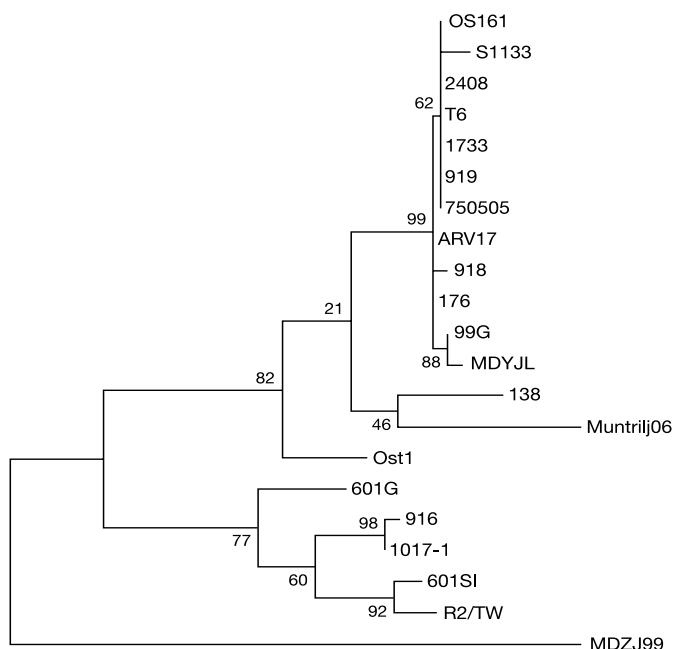

10
Fig. 1. Unrooted phylogenetic tree based on the nucleotide sequences of the sigma A encoding gene of 21 ARV strains using maximum parsimony and 500 bootstrap replicates. The numbers near the branches indicate the confidence level calculated with bootstrap. The units at the bottom of the tree indicate the number of substitution events

samples from turkeys younger than and in one turkey at 6 weeks of age. Amplified fragments originating from spleen corresponded to $\sim 1650 \mathrm{bp}$. In 17/23 intestinal content samples 849 bp-product of TAstV-2 capsid gene was detected. A 460 bp-band which corresponds to ARV S3 gene was present only in positive control sample. A 626-bp band of sigma A (S2) encoding gene segment from avian reovirus was present in three samples originating from the intestinal content and positive control sample. Obtained PCR products were sequenced and 450-bp fragment of sigma A encoding gene of our strain Muntrilj06 was analyzed. When aligned with the corresponding nucleotide sequences published for ARV isolates worldwide, an identity of $91.3 \%$ was found with the strains 138 (AF059717), 2408 (AF247724), 1733 (AF293773), 919 (AF294763), T6 (AF294768), and Os161 (AF 294770). The amino acid sequence similarity between strains used in the study was higher than nucleotide sequence similarity (between 95.3 and 96.6\%). Phylogenetic analysis of the corresponding fragment of the sigma A encoding gene of our isolate with representative ARV isolates revealed two clusters, but Muntrilj06 was more related to 138 and Ost1 (Fig. 1). No TCV specific PCR band was found in any sample. Four flocks were positive simultaneously on HEV and TAstV-2, and three flocks on TastV-2 and ARV.

\section{Discussion}

Even if our results have similarity with published reports on the survey of enteric viruses in commercial turkeys (Reynolds et al. 1987ab; Yu et al. 2000; Pantin-Jackwood et al. 2007), this is the first report on the prevalence of enteric viruses in Croatian turkey flocks and is based on sensitive molecular techniques and characterization of ARV by sequence analysis.

The first investigations about pathogenicity of the reovirus in the stunting syndrome were made by $\mathrm{Yu}$ et al. (2000) who concluded that it is not an important pathogen for clinical symptoms of the disease. However, Heggen-Peay et al. (2002) demonstrated that strain ARV CU98 isolated from PEMS poults does cause some of the clinical signs in PEMS. We aligned published S3 sequences of NC 98, PEMS 85 and TX and designed primers which amplify 460 bp-portion of S3 gene. No ARV positive band was found in any investigated sample, but positive control sample revealed expected product, confirming the specificity of reaction. Oligonucleotide primers PAF/PAR described by Zhang et al. (2006) were also used. It amplifies 626-bp sigma A encoding gene and is designed by aligning nine ARV and three duck reoviruses. Three samples were positive, one from 2005 and two from 2006, all from the same farm. Obtained PCR products were sequenced and analyzed. Sequence and phylogenetic analysis of a 450-bp fragment of sigma A encoding gene showed that sequence of our strain Muntrilj06 were most related to chicken ARV isolate 138. 
After our first turkey specific ARV-PCR did not yield positive results, and again, S2 specific PCR was positive because the primers were more degenerate and able to detect ARV from various types of poultry, we suspected arthritis/tendosynovitis. But pathological findings related to arthritis (e.g., swelling of tendons) was not visible, poults just suffer from leg weakness. So, further experiments with designing primers that could amplify other ARV genes, isolation of ARV from poults, and challenge experiments are necessary.

A characteristic fragment corresponding to 849 bp-part of TAstV-2 capsid gene was found in 17 samples, as well as in a positive control sample. All positive samples were from the flocks from two to five weeks of age. PEC is an infectious disease characteristic for poults aged up to six weeks (Barnes et al. 2000). It is often multicausal, although there are some findings about pathogenicity of astroviruses alone (Thouvenelle et al. 1995a; 1995b; Reynolds and Saif 1986; Qureshi et al. 2000). Reynolds et al. (1987a) detected astroviruses in $78 \%$ of turkey flocks with diarrhoea. So, it is not surprising that investigated flocks were positive for TAstV-2. TAstV-2 primarily replicates in the thymus (Qureshi et al. 2000), and it weakens the turkey's immune system. So, even if it is responsible for causing the disease alone (Reynolds and Saif 1986), due to immunosuppression, infection with other viruses such as ARV, TCV and HEV, occurs.

All the examined samples of intestinal suspensions were TCV-PCR negative. Primers for detection of TCV described by Sellers et al. (2004) which amplify a 598-bp fragment within the $\mathrm{N}$ gene of TCV were selected for use in these assays. No TCV positive band was found in any investigated sample, but positive control sample revealed the expected product, confirming the specificity of reaction. Contribution to this fact lies in the investigation of Barnes et al. (1997) who proved that symptoms of enteritis could be induced by other viruses with no co-infection with TCV. Carver et al. (2001) also found flocks that suffered from enteritis and were negative for TCV.

For detection of HEV we used primers described by Hess et al. (1999) which amplify $1656 \mathrm{bp}$-fragment of HEV hexon gene. It is based on detection of loop regions in the HEV hexon gene which have low sequence identity with other fowl adenoviruses. Multiple infections with HEV and TAstV-2 were detected in four flocks at three, four and five weeks of age, respectively (Table 2). Haemorrhagic enteritis is a disease of turkeys most often of 4-11 weeks of age (Pierson and Domermuth 1997), but we detected the virus in turkeys at three weeks of age. It is also an immunosuppressive disease, HEV replicates in the spleens and caecal tonsils of infected turkeys (Suresh and Sharma 1996). From its first outbreak in 1979, infections of turkeys with HEV were sporadic. So, the virus probably exists in a turkey flock constantly. Every adverse effect, even a relatively short period of stress, weakens the turkeys' immune systems which results in increased mortality. The second outbreak of HE was detected in fattening turkeys in 2001 when $75 \%$ of examined sera samples were positive (Amšel Zelenika et al. 2003). Serological, or in our case, genomic evidence of the presence of HEV in a turkey flock means the evidence of natural infection, since, in Croatia, specific immunoprophylaxis for HEV is not in use. We can also conclude that the second outbreak is finished since no sample after 2004 was HEV positive.

Even though it is a production disease, PEC is not solely caused by specific enteric viruses that are involved in the pathophysiology of the disease. The combination of enteric viruses involved in poult enteritis described here is different than those described in studies from other countries. In our case we found adenoviruses even in very young turkeys; our reovirus is different from PEMS reoviruses; and coronavirus was not present. Based on this study, we believe that the severity of the disease is caused by immunosuppressive TastV-2 in combination with HEV or ARV. 


\section{Acknowledgements}

This research was supported by grant No. 053-0531863-1856 from the Ministry of Science, Education and Sports, Republic of Croatia.

\section{References}

Amšel Zelenika T, Biđin Z, Tišljar M, Ćurić S, Mikec M, Lojkić I, Volarević S, Stanišić Ž 2003: The Incidence of Haemorrhagic Enteritis in Intensive Turkey Production. In: $5^{\text {th }}$ Symposium Poultry Days 2003 with international participation, Poreč, Croatia (Wittner V, Ed.) pp. 153-156

Barnes HJ, Guy JS, Vaillancourt JP 2000: Poult enteritis complex. Rev Sci Tech 19: 565-588

Barnes HJ, Guy JS 2003: Poult enteritis-mortality syndrome ("spiking mortality") of turkeys. In: Barnes HJ, Glisson JR, Fadly AM, McDougald LR, Saif YM, Swayne DE (Eds.): Diseases of poultry, $11^{\text {th }}$ ed. Iowa State University Press, Ames, IA, pp. 1171-1180

Barnes HJ, Guy JS, Weaver JT, Jennings SR 1997: Turkey flocks with high spiking mortality that are negative for turkey coronavirus. In: Proceedings of the $134^{\text {th }}$ Annual Convention of the American Veterinary Association, Reno, Nevada, USA, $169 \mathrm{p}$.

Breslin JJ, Smith LG, Fuller TJ, Guy JS 1999: Sequence analysis of the turkey coronavirus nucleocapsid gene and 3 untranslated region identifies the virus as a close relative of infectious bronchitis virus. Virus Res $\mathbf{6 5}$ : 187-198

Bridger JC 1980: Detection by electron microscopy of caliciviruses, astroviruses and rotavirus-like particles in the faeces of piglets with diarrhea. Vet Rec 107: 532-533

Carver DK, Vaillancourt JP, Stringham M, Guy JS, Barnes HJ 2001: Mortality patterns associated with poult enteritis mortality syndrome (PEMS) and coronaviral enteritis in turkey flocks raised in PEMS-affected regions. Avian Dis 45: 985-91

Culver F, Dziva F, Cavanagh D, Stevens MP 2006: Poult enteritis and mortality syndrome in turkeys in Great Britain. Vet Rec 159: 209-210

Dea S, Verbeek AJ, Tijssen P 1990: Antigenic and genomic relationships among turkey and bovine enteric coronaviruses. J Virol 64: 3112-3118

Goodgame RW 2001: Viral causes of diarrhea. Gastroenterol Clin N Am 30: 779-795

Guy JS, Barnes HJ, Smith LG, Breslin J 1997: Antigenic characterization of a turkey coronavirus identified in poult enteritis- and mortality syndrome-affected turkeys. Avian Dis 41: 583-590

Heggen-Peay CL, Qureshi MA, Edens FW, Sherry B, Wakenell PS, O'Connell PH, Schat KA 2002: Isolation of a reovirus from Poult Enteritis and Mortality Syndrome and its pathogenicity in turkey poults. Avian Dis 46: $32-47$

Hess M, Raue R, Hafez HM 1999: PCR for specific detection of haemorrhagic enteritis virus of turkeys, an avian adenovirus. J Virol Meth 81: 199-203

Imada TS, Yamaguchi S, Mase M, Tsukamoto K, Kubo M, Morooka A 2000: Avian nephritis virus (ANV) as a new member of the family Astroviridae and construction of infectious ANV cDNA. J Virol 74: 8487-8493

Koci MD, Seal BS, Schultz-Cherry S 2000: Molecular characterization of an avian astrovirus. J Virol 74: 6173-6177

Kumar S, Tamura K, Nei M 2004: MEGA3: integrated software for molecular evolutionary genetics analysis and sequence alignment. Brief Bioinform 5: 150-163

Lai MCM, Cavanagh D 1997: The molecular biology of coronaviruses. Adv Vir Res 48: 1-100

Lin TL, Wu CC, Porter RE, Thacker HL, Bryan TA, Kanitz CL, Hermes D, Schrader DL, Woodruff MM, Hooper TA 1996: Turkey poult enteritis caused by turkey coronavirus. JAVMA 209: 372

Mazija H, Biđin Z, Pilat Z 1979: Hemoragični enteritis purana. I. Pojava i značaj u intenzivnom uzgoju purana. Vet Arhiv (Suppl.1) 49: 55-58

McNulty MS, Curran WL, McFerran JB 1980: Detection of astroviruses in turkey faeces by direct electron microscopy. Vet Rec 106: 561

Nagaraja KV, Pomeroy BS 1997: Coronaviral enteritis of turkeys (bluecomb disease). In: Calnek BW, Barnes HJ, Beard CW, Mcdougald LR, Saif YM (Eds): Diseases of poultry, $10^{\text {th }}$ ed. Ames: Iowa State University Press, Ames IA, pp. 686-692

Naqi SA, Panigrahy B, Hall CF 1972: Bursa of Fabricius, a source of bluecomb infectious agent. Avian Dis 16: 937-939

Pantin-Jackwood MJ, Spackman E, Day JM 2007: Periodic monitoring of commercial turkeys for enteric viruses indicates continuous presence of astrovirus and rotavirus on the farms. Avian Dis 51: 674-680

Patel BL, Deshmukh DR, Pomeroy BS 1975: Fluorescent antibody test for rapid diagnosis of coronaviral enteritis of turkeys (bluecomb). Am J Vet Res 36: 1265-1267

Pierson WF, Domermuth CH 1997: Haemorrhagic enteritis, marble spleen disease and related infections. In: Calnek BW, Barnes HJ, Beard CW, McDougald LR, Saif YM (Eds): Diseases of Poultry, $10^{\text {th }}$ ed. Iowa State University Press, Ames, IA, pp. 624-633

Qureshi MA, Yu M, Saif YM 2000: A novel "small round virus" inducing poult enteritis and mortality syndrome and associated immune alterations. Avian Dis 44: 275-283 
Reynolds DL, Saif YM 1986: Astrovirus: a cause of an enteric disease in turkey poults. Avian Dis 30: 728-735

Reynolds DL, Saif YM, Theil KW 1987a: A survey of enteric viruses of turkey poults. Avian Dis 31: 89-98

Reynolds DL, Saif YM, Theil KW 1987b: Enteric viral infections of turkey poults: incidence of infection. Avian Dis 31: 272-276

Rosenberger JK, Olson NO 1997: Viral arthritis. In: Calnek BK, Barnes HJ, Beard CW, McDougald LR, Saif YM (Eds): Diseases of Poultry. $10^{\text {th }}$ ed. Iowa State University Press Ames, IA, pp. 711-719

Saif LJ, Saif YM, Theil KW 1985: Enteric viruses in diarrheic turkey poults. Avian Dis 29: 798-811

Sellers HS, Koci MD, Linnemann E, Kelley LA, Schultz-Cherry S 2004: Development of a multiplex reverse transcription-polymerase chain reaction diagnostic test specific for turkey astrovirus and coronavirus. Avian Dis 48: $531-539$

Simmons VM, Koci MD, Kapczynski DR, Schultz-Cherry S 2000: Initial characterization of an avian reovirus isolated from turkey poults with poult enteritis and mortality syndrome. Poult Sci 79 (Suppl. 1): 120

Suresh M, Sharma JM 1996: Pathogenesis of type II avian adenovirus infection in turkeys: in vivo immune cell tropism and tissue distribution of the virus. J Virol 26: 158-163

Thouvenelle ML, Haynes JS, Reynolds DL 1995: Astrovirus infection in hatchling turkeys: histologic, morphometric, and ultrastructural findings. Avian Dis 39: 328-336

Thouvenelle ML, Haynes JS, Sell JL, Reynolds DL 1995: Astrovirus infection in hatchling turkeys: alterations in intestinal maltase activity. Avian Dis 39: 343-348

Verbeek A, Tijssen P 1991: Sequence analysis of the turkey enteric coronavirus nucleocapsid and membrane protein genes: a close genomic relationship with bovine coronavirus. J Gen Virol 72: 1659-1666

Yu M, Ismail MM, Qureshi MA, Dearth RN, Barnes HJ, Saif YM 2000: Viral agents associated with poult enteritis and mortality syndrome: the role of a small round virus and a turkey coronavirus. Avian Dis 44: 297-304

Zhang Y, Liu M, Shuidong O, Hu QL, Guo DC, Chen HY, Han Z 2006: Detection and identification of avian, duck, and goose reoviruses by RT-PCR: goose and duck reoviruses are part of the same genogroup in the genus Orthoreovirus. Arch Virol 151: 1525-1538 
